\title{
Protein Pattern Measurement
}

National Cancer Institute

\section{Source}

National Cancer Institute. Protein Pattern Measurement. NCI Thesaurus. Code C147422.

An assessment of the protein band pattern present in a sample. 